\title{
Marketing of menthol cigarettes and consumer perceptions: a review of tobacco industry documents
}

\author{
Stacey J Anderson ${ }^{1,2}$
}

${ }^{1}$ Department of Social and Behavioral Sciences, University of California, San Francisco (UCSF), California, USA ${ }^{2}$ Center for Tobacco Control Research and Education, UCSF, California, USA

\section{Correspondence to}

Stacey J Anderson, Department of Social and Behavioral Sciences, Box 0612, University of California, San Francisco, CA 94143-0612, USA;

stacey.anderson@ucsf.edu

Received 17 November 2010 Accepted 29 January 2011

\begin{abstract}
Objective To examine tobacco industry marketing of menthol cigarettes and to determine what the tobacco industry knew about consumer perceptions of menthol. Methods A snowball sampling design was used to systematically search the Legacy Tobacco Documents Library (LTDL) (http://legacy.library.ucsf.edu) between 28 February and 27 April 2010. Of the approximately 11 million documents available in the LTDL, the iterative searches returned tens of thousands of results from the major US tobacco companies and affiliated organisations. A collection of 953 documents from the 1930s to the first decade of the 21 st century relevant to 1 or more of the research questions were qualitatively analysed, as follows: (1) are/were menthol cigarettes marketed with health reassurance messages? (2) What other messages come from menthol cigarette advertising? (3) How do smokers view menthol cigarettes? (4) Were menthol cigarettes marketed to specific populations?
\end{abstract}

Results Menthol cigarettes were marketed as, and are perceived by consumers to be, healthier than non-menthol cigarettes. Menthol cigarettes are also marketed to specific social and demographic groups, including African-Americans, young people and women, and are perceived by consumers to signal social group belonging.

Conclusions The tobacco industry knew consumers perceived menthol as healthier than non-menthol cigarettes, and this was the intent behind marketing. Marketing emphasising menthol attracts consumers who may not otherwise progress to regular smoking, including young, inexperienced users and those who find 'regular' cigarettes undesirable. Such marketing may also appeal to health-concerned smokers who might otherwise quit.

\section{INTRODUCTION}

The concentration of menthol in tobacco products varies according to the product characteristics and the perceived flavour desired, but is present in $90 \%$ of all tobacco products, whether the products are marketed specifically as 'mentholated' or not. ${ }^{12}$ The Family Smoking Prevention and Tobacco Control Act (FSPTCA) gave the US Food and Drug Administration (FDA) regulatory authority over tobacco products. On 22 September 2009, the FDA exercised this authority when it announced a rule banning cigarette flavourings specified in the Act. This ban did not include menthol, however, as it was excluded from the list of banned flavourings in the Act because of opposition by the tobacco industry. The fact that menthol was not included in the original list of banned flavours concerned many in the public health arena who argued that menthol is used by the tobacco industry to attract young, inexperienced smokers and/or AfricanAmericans. ${ }^{3}$ In addition to youth appeal, the addition of 'medicinal menthol' to cigarettes may also appeal to established health-concerned smokers who might otherwise quit. ${ }^{4}$

Others have investigated the internal tobacco industry documents for different but related questions on how tobacco companies manipulate menthol content in cigarettes to target young people $e^{5}$ and consumer perceptions of the sensory characteristics of menthol. ${ }^{6}$ This paper analyses internal tobacco industry documents to determine if tobacco companies marketed mentholated cigarettes as public health advocates allege, and how the tobacco industry managed consumer perceptions of menthol through marketing strategies. This knowledge can help inform the regulatory decisions by the US FDA and comparable agencies elsewhere in the world, and can augment public health's understanding of why the tobacco industry opposed menthol's inclusion in the list of banned flavouring additives.

Academics and government scientists independent of the tobacco industry have shown that the tobacco industry targets various population groups, including specific racial and ethnic populations, with marketing and advertising generally ${ }^{7}$ and for mentholated products specifically. ${ }^{8}$ A 2006 case study ${ }^{9}$ of Kool, Brown \& Williamson's best selling mentholated brand, described the company's use of music events to promote the brand to young, particularly African-American, people. Independent research has shown explicit and implicit health messages in advertisements for menthol cigarettes. $^{10} 11$ Some health messages are explicit, for example, in a 1942 advertisement asking 'Throat sore? Time to give it a rest!' and directing the reader to 'Change to Spuds. Enjoy their soothing coolness!' (the Spud brand was the first in the US to advertise that it was mentholated). It is nevertheless important to examine the intentions behind the creation of such marketing communications in the words of tobacco company insiders themselves, particularly if marketing shifted from communicating this type of explicit health message to messages that continue to communicate health benefits, but less explicitly. ${ }^{10} 11$ The current study begins with historical examples and moves forward in time, but is not a strictly chronological treatment of the topic. The results are presented in three overall sections: marketing messages for menthol cigarettes, then consumer perceptions of those messages, and specific populations targeted by such messages.

A decline in per capita cigarette consumption in the US in 1953-1954 resulting from the "health 
scare' marked the beginning of changes in health-related messages in cigarette marketing materials. ${ }^{12}$ A decade later, after the 1964 US Surgeon General's Report 'Smoking and Health'13 and the 1965 Cigarette Act, ${ }^{14}$ US tobacco marketers continued to be faced with the challenge of marketing a product identified as harmful by health authorities while distracting consumers from those known harms. These challenges necessitated a move away from explicit health messages and towards other messages that would appeal to different groups of potential consumers of 'low-tar' or 'light' tobacco products. Research has elucidated many of these alternative marketing messages for 'low-tar' and 'light' cigarettes, ${ }^{415}$ and has demonstrated that consumers tend to perceive 'low-tar' and 'light' cigarettes to be less harmful than 'regular' cigarettes. ${ }^{16-20}$ less is understood about messages for menthol cigarettes or about how consumers perceive menthol. A 2010 scholarly commentary stated that the industry has used menthol's association with cold remedies to infer that smoking menthol cigarettes has some medicinal or health benefit for more than 70 years'. ${ }^{21}$ Internal documents can shed light on whether consumers have accepted this inference of health benefits.

This paper addresses the following questions on marketing for and consumer perceptions of menthol cigarettes:

1. Are/were menthol cigarettes marketed with health reassurance messages?

2. What other messages come from menthol cigarette advertising?

3. How do smokers tend to view menthol cigarettes?

4. Were menthol cigarettes marketed to specific populations?

\section{METHODS}

A complete discussion of the general tobacco documents research methods employed in this study is found elsewhere in this issue. ${ }^{22}$ Details specific to the current study are as follows: in this qualitative research study of the digitised repository of previously internal tobacco industry documents, a snowball sampling design ${ }^{23}$ was used to search the Legacy Tobacco Documents Library (LTDL) (http://legacy.library.ucsf.edu). The LTDL was systematically searched between 28 February and 27 April 2010, using standard documents research techniques. These techniques combine traditional qualitative methods ${ }^{24}$ with iterative search strategies tailored for the LTDL data set. ${ }^{25}$

Initial keyword searches combined terms related to: menthol, health/healthy/healthier, cool/cooling/cooler, market/markets/ marketing, consumer perception, focus group, creative, advertisement copy, communication, market research, report, topline and target group. This initial set of keywords resulted in the development of further search terms and combinations of keywords (eg, menthol cigarette brand names, project names, individuals and companies named in correspondences and on research reports, and specific target groups). For each set of results, the first 50-300 documents were reviewed. If documents did not appear to be relevant to the research questions, or if there was a repetitive pattern of documents, the review moved on to the next search term. Among the reports, correspondence and studies conducted by product development and research departments of the major tobacco companies (American Tobacco (AT), British American Tobacco (BAT), Brown \& Williamson (B\&W), Lorillard, Philip Morris (PM) and RJ Reynolds (RJR)), relevant documents were found in the following subject areas: (1) marketing menthol using health assurance messages; (2) user-imagery focused marketing; (3) consumer perceptions of menthol products; and (4) targeting specific populations. A final collection of 953 documents, created between the 1930s to the first decade of the 21st century, relevant to 1 or more of the research questions were qualitatively analysed. Memos were written to summarise the relevant documents to further narrow down to the 60 representative documents that are cited in this paper.

\section{RESULTS}

\section{Health reassurance messages in menthol advertising}

Menthol cigarettes were marketed using health reassurance messages suggesting that menthol cigarettes were safer than 'full flavour' or non-menthol cigarettes. The first mentholated cigarette is credited to a young man, Lloyd 'Spud' Hughes, a chronic cold sufferer, when in the 1920s his mother prescribed a treatment of menthol crystals that he surreptitiously added to his smoking tobacco tin. ${ }^{26} 27$ Bearing Hughes's nickname, Spud cigarettes became the first commercial menthol brand to be marketed in the US; B\&W followed with Kool Menthol in 1933. Initially Kool Menthol, and menthol in general, was advertised as being 'for occasional use' in order to 'rest your throat ${ }^{28}$ rather than a regular, daily-use product.

Menthol cigarettes were first popularised as a remedy to the burn, dryness and throat irritation that accompany smoking (figure 1). B\&W and Lorillard marketed menthols with healthreassuring slogans such as 'Breathe easy, smoke clean', 'When your throat tells you it's time for a change...'29 and 'The beneficial head-clearing qualities of menthol'. 30 Similar claims made were that menthol brands act as a 'remedy or treatment for coughs' and counteract 'throat irritations due to heavy smoking' 31

Tobacco company executives sought to emphasise health messages in the marketing of menthol products relative to non-menthol products from the beginning. The advertising firm Cunningham \& Walsh compiled a report for B\&W in 1980 in which they observed that Kool's '( $\mathrm{r}$ )emedial specialty brand image' in the early 1950s 'benefits (the b)rand as smokers perceive menthol as less harmful'. ${ }^{32}$ In a 1960s brand evaluation, $\mathrm{B} \& \mathrm{~W}$ noted that '(e)mphasis on the throat, with its important
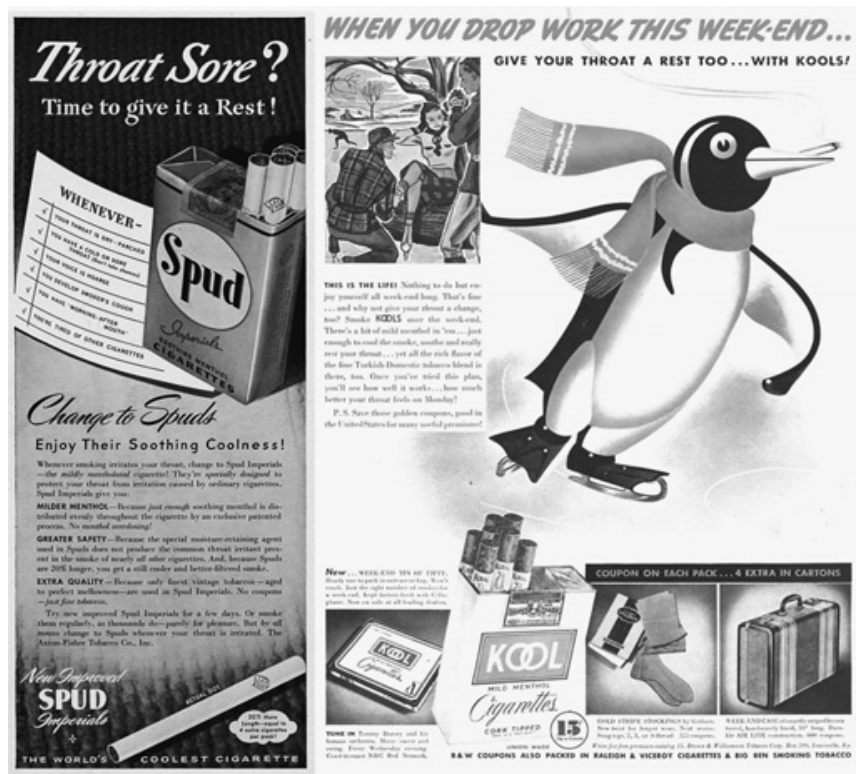

Figure 1 Spuds brand and Kool brand cigarettes, the earliest two brands to be marketed specifically as mentholated brands in the US, were presented in the 1920s and 1930s as brands that provide relief from the throat pain and irritation caused by smoking (images retrieved from http://lane.stanford.edu/tobacco/index.html). 
health implications, has... been an important part of Kool advertising since 1960' ${ }^{33}$ According to a 30 May 1973 Lorillard meeting agenda to discuss 'Kent Menthol 100's', the objective of a menthol line extension of Lorillard's 'low tar' Kent brand was to 'convince smokers of competitive menthols (as well as smokers contemplating entering the category) that Kent menthol is the menthol that offers refreshing menthol smoking satisfaction and health reassurance'. ${ }^{34} \mathrm{~B} \& \mathrm{~W}$ declared that 'KOOL must move into the health reassurance segment so that $45 \%$ of KOOL business will be in the perceived product safety arena by 1982 '. 35

\section{Other messages in menthol cigarette advertising}

The 1950s marked the beginning of significant public awareness in the US of the health hazards of smoking. ${ }^{36}$ With the introduction of RJR's Salem brand in 1956, the ostensible 'health' benefit of menthol was overtaken by the 'taste' benefit of menthol, and menthol as a cigarette style moved from the occasional into the regular use arena. ${ }^{37}$ The importance of this shift was neatly explained in a 1982 B\&W market presentation:

\section{Salem created a whole new meaning for menthol. From the heritage of solves-the-negative-problem-of-smoking, menthol almost instantly became a positive smoking sensation. Menthol in the filter form in the Salem advertising was a 'refreshing' taste experience. It can be viewed as very 'reassuring' in a personal concern climate. Undoubtedly, the medicinal menthol connotation carried forward in a therapeutic fashion, but as a positive taste benefit. ${ }^{37}$ (Emphasis added.)}

The Newport brand's entry into the market in 1957 with the advertising slogan 'Rich taste-with a touch of refreshing mint' made menthol 'now a positive experience, not just a solver of smoking "problems". 37 Being aware that menthol also carried health connotations, tobacco companies were freed up to market menthol cigarettes as a thing of pleasure and personal preference while still providing health reassurances to menthol smokers.

\section{Refreshing, fresh, cool and clean}

Avoiding overt health messages by the late 1950s, Kool advanced new advertising copy such as, "What a wonderful difference when you switch to snow fresh KOOLs. Your mouth feels clean and cool, your throat feels soothed and fresh. Enjoy the most refreshing experience smoking' ${ }^{38}$ By the 1960s Kool advertising employed implicit health-related messages in print advertisements for college, military, and 'Negro' publications, such as 'Only KOOL gives you real menthol magic' or 'Come all the way up to KOOL Filter Kings for the most refreshing coolness you can get in a cigarette', ${ }^{38}$ capitalising on the perception of cooling as healthier.

Smokers describe menthol's 'cooling' or 'refreshing' effects variably as a taste or flavour on the one hand, or a sensation or impact on the other hand. A 1988 Philip Morris (PM) study of the menthol market noted that 'menthol's appeal primarily focused on the unique feeling or sensation it provides', and that 'menthol taste (is) more difficult to describe than menthol sensation'. ${ }^{39}$ Menthol cigarette marketers were quick to exploit the perception of menthol as a sensation in addition to a taste. Major objectives for the Kool brand family from 1979 to 1985 included the necessity 'to enhance the perception of the two major menthol buying motivations-satisfaction and refreshment'. ${ }^{35}$ ADI Research, Inc. advised B\&W similarly in a 1984 cigarette smokers study that 'frequently mentioned positive characteristics of Kool Filter Kings were refreshingness, coolness, smell, sensation, and smoothness' 40 That year, Cunningham and Walsh advised B\&W to forge Kool's popularity worldwide by positioning the brand as 'something enjoyable from US, most refreshing taste sensation'. ${ }^{41}$ Figure 2 shows some examples of 'refreshing' and 'cool' messages.

Although there was shift away from overt health messages towards less tangible 'refreshment' and similar messages in menthol marketing triggered by the health scare of the 1950s, tobacco companies still wished to maintain health associations with menthol. According to a B\&W brand planning document in 1978 (estimated date), a prime Kool objective for 1979-1985 was also to '( $p$ )rovide product safety reassurance while enhanc(ing) the satisfaction and refreshment perception of the appropriate KOOL styles, through the successful, national launch in 1979 of either: 1. Low-'tar' parent (or) 2. Repositioned KOOL Milds'. ${ }^{35}$

\section{Identity and in-group belonging}

Menthol is commonly thought of as an African-American cigarette style in the US market, and to an extent, evidence from industry documents supports this perception. However, tobacco companies do not intend for menthol to be only or even mostly an African-American style, but rather a cigarette style associated with group identity for various subgroups in the market, including, but not exclusively, African-American identity.

Some industry analysts, such as Diane Burrows of the RJR Marketing Development Department (a competitor of B\&W), observed a change in the cigarette market, particularly in the menthol market, in the 1960s. In her 1984 analysis of RJR's Salem, Lorillard's Newport and B\&W's Kool, Burrows stated:

\begin{abstract}
Younger adult Blacks of the 1930s to 1950s had basically gone with whatever brand was big among younger adult White smokers... In the 1960s, they began to coalesce behind Kool, which only had a $2 \%$ share among younger adult Whites. It was time for Blacks to build their own brand in the 1960s, the heyday of Martin Luther King and 'Black pride'. ${ }^{2}$
\end{abstract}

The strategy for exploiting this phenomenon was simple:

Kool apparently capitalized on this aspect of the 1960s by simply advertising to Blacks before its competitors did. Kool ads were in

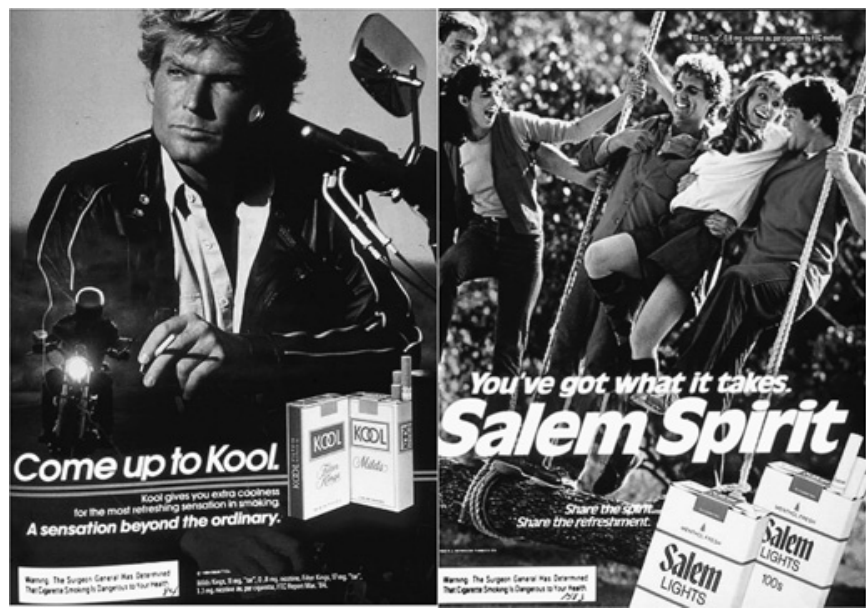

Figure 2 Triggered by the health scare of the 1950s and increasing after the 1964 US Surgeon General's Report, advertisements for menthol brands emphasised general refreshment and coolness rather than the explicit health messages of earlier decades. Menthol nevertheless continued to carry the medicinal and health connotations of previous decades (images from the 1980s, retrieved from http://www.tobacco.org/ads). 
Ebony consistently from at least 1962, when our records start.... Kool became 'cool' and, by the early 1970s, had a 56\% share among younger adult Blacks-it was the Black Marlboro. ${ }^{42}$

Without referencing Dr King or 'black pride' specifically, B\&W stated in a 1966 marketing analysis company presentation that the brands 'perform very well in ethnic markets because for some time we have been tailoring our advertising to fit local markets'. ${ }^{43}$ Further, in a 1969 marketing report, B\&W stated that Kool 'continues to direct advertising towards specific ethnic groups with special emphasis on the Negro market'. ${ }^{44}$

In 1979, B\&W explicitly planned to '(e)nhance the social acceptance of the entire KOOL line through all creative efforts so that the product is equally acceptable to White smokers-as to Black smokers. This will be realized through smoker image creative management as well as specific media targeting, ${ }^{35}$ By 1983, M. A. Schreiber, Kool's Senior Brand Manager for B\&W, wrote:

In January, 1982, KOOL launched its current campaign. Pan-racial music imagery was established as KOOL's strategic property.... (A) $\mathrm{n}$ advertising exploratory was started to ...specifically address how to communicate... (a)n attractive, contemporary image to young adult Whites. ${ }^{45}$

An urban image, which appealed to young people of many ethnicities, continued to be important to menthol marketing through the 1990s. Advertising agency Leo Burnett reported to PM in December 1995 that among 'urban dwellers, ages LA-24 (legal age to age 24), African-American and Caucasian, menthol loyalists... (u)rban terminology transcends beyond the AfricanAmerican community'. ${ }^{46}$ The agency tested marketing creatives (mock-up advertisements for participant feedback), including '(m)enthol approaches tied to identified urban smoker insights' with the theme 'Diversity/Community' ${ }^{46}$ One specific creative in the 'Diversity/Community' theme titled 'Huze Art' was observed by the agency to be '(b)y far the strongest of the approaches, its appeal was driven by the sense of urban multiculturality expressed through art'. ${ }^{46}$ The appeal of this execution was explained as follows:

- Urban lifestyle crosses ethnic boundaries.

- Urban lifestyle appeals outside of urban boundaries. ${ }^{46}$

To attach a menthol brand to in-group identity, Kapuler Marketing Research, Inc. conducted a study of a new campaign for Kool targeting ethnic Hawaiians in 1988 for B\&W, titled 'Kool and Mild Today'. The agency concluded '( $t$ )he use of ethnic models is seen as something new and respondents are generally positive about this concept. It could provide an opportunity for KOOL to capitalize on being the first to employ ethnic advertising in Hawaii'. ${ }^{47}$ The agency noted the models should not look too Japanese but rather should appear to be ethnic Hawaiian Islanders. Preferred models were described as 'fun, happy-go-lucky young people in their $20 \mathrm{~s}$. They have full social calendars and spend a lot of time outdoors at the beach... people who display what islanders call the aloha spirit. ${ }^{47}$

\section{Fun loving, sociable and youthful}

RJR noted in 1981 that the 'Coolness Segment' (RJR's term for the menthol market, describing the cooling properties of menthol) is the youngest of all cigarette market segments. ${ }^{48} \mathrm{RJR}$ stated in 1981 that '(a)dvertising must convince younger adult smokers that SALEM is smoked by natural, unpretentious but interesting people who are social leaders/catalysts (make things happen) whose sense of humor and wit makes them fun and exciting to be with'. ${ }^{49}$
Youthfulness and sociability are not images restricted to menthol users. Social interaction is thought by tobacco marketers to be important to young adults and adolescents in general. RJR observed in 1981 that:

(s)moking is frequently used in situations when people are trying to make friends, to look more mature, to look more attractive, to look 'cooler', and to feel more comfortable around others. These aspects of social interaction are especially prevalent among younger adult smokers.... The benefit of smoking which has most frequently and most successfully been exploited by brand families appears to be Social Interaction. For example, some brands, such as Newport, have focused on the younger adult 'peer group' aspect of social interaction. ${ }^{50}$

These user images carry particular weight within the menthol market. Speaking specifically about target users of a new Salem Lights $100 \mathrm{~mm}$ product, RJR asserted in 1982 that 'user imagery reflects aspirations of the Personal Experience segment identified by Yankelovich (Inc., a consumer research company).... The lifestyle of the Personal Experience segment is defined as seeking direct experience and excitement... social interaction is a key element to personal fulfillment'. ${ }^{51}$ The emphasis on sociability, fun and enjoyment is particularly evident in Lorillard's longrunning Newport 'Alive with Pleasure' campaign. ${ }^{52}$ These messages of sociability, fun and enjoyment proved so popular with young audiences that RJR created their 'Salem Spirit' campaign to communicate the values 'sociable' and 'have a good time ${ }^{,},{ }^{53}$ though they noted problems with consumers confusing the campaign with Lorillard's similar Newport campaigns. PM observed in 1995 that Newport's '(c)onsistent theme ('Alive with Pleasure') and strategy ('Friends having fun') have given Newport a clear identity in smokers minds', that Newport was '(t)he only brand to capitalized on important 'sociability' aspect of category'. ${ }^{54}$ Figure 3 shows a 'Newport Pleasure' campaign advertisement that communicates sociability and in-group belonging. It is perhaps menthol's younger profile relative to non-menthol that makes youthfulness and sociability particularly important to many menthol smokers.

\section{Consumer perceptions of menthol marketing messages}

Menthol smokers view menthol cigarettes as safer or less harmful than 'full flavour' or non-menthol cigarettes. Menthol smokers sometimes identified safety perceptions explicitly, but sometimes implicitly with terms such as 'mild', 'light', 'cooling', or 'soothing'; terms that suggest relative safety or health benefits. Terms that imply health messages, including 'light' and 'mild', have been determined to be deceptive in federal Judge Gladys Kessler's ruling that the US cigarette manufacturers violated the Racketeer-Influenced and Corrupt Organizations Act $(\mathrm{RICO})^{55}$ as well as by Congress in the FSPTCA.

A focus group study conducted for American Tobacco in 1969 tested, in part, perceptions of a new menthol product. It was observed that:

Menthol smokers indicated that they smoked menthol cigarettes because they were 'mild', 'cooling', 'refreshing', and 'soothing to the throat'.... There were indications that the menthol smokers subconsciously perceived menthol cigarettes as being healthier. There was somewhat of a 'health image' associated with menthol, related to its masking of the tobacco taste, and its association with medicine, colds, and sore throats. ${ }^{56}$ (Emphasis added.)

In 1976, B\&W noted that 'evidence indicates that a pseudo-health image has accrued to mentholated cigarettes' ${ }^{57}$ Then, 2 years later, B\&W explicitly acknowledged its Kool franchise '(r)ides on the 


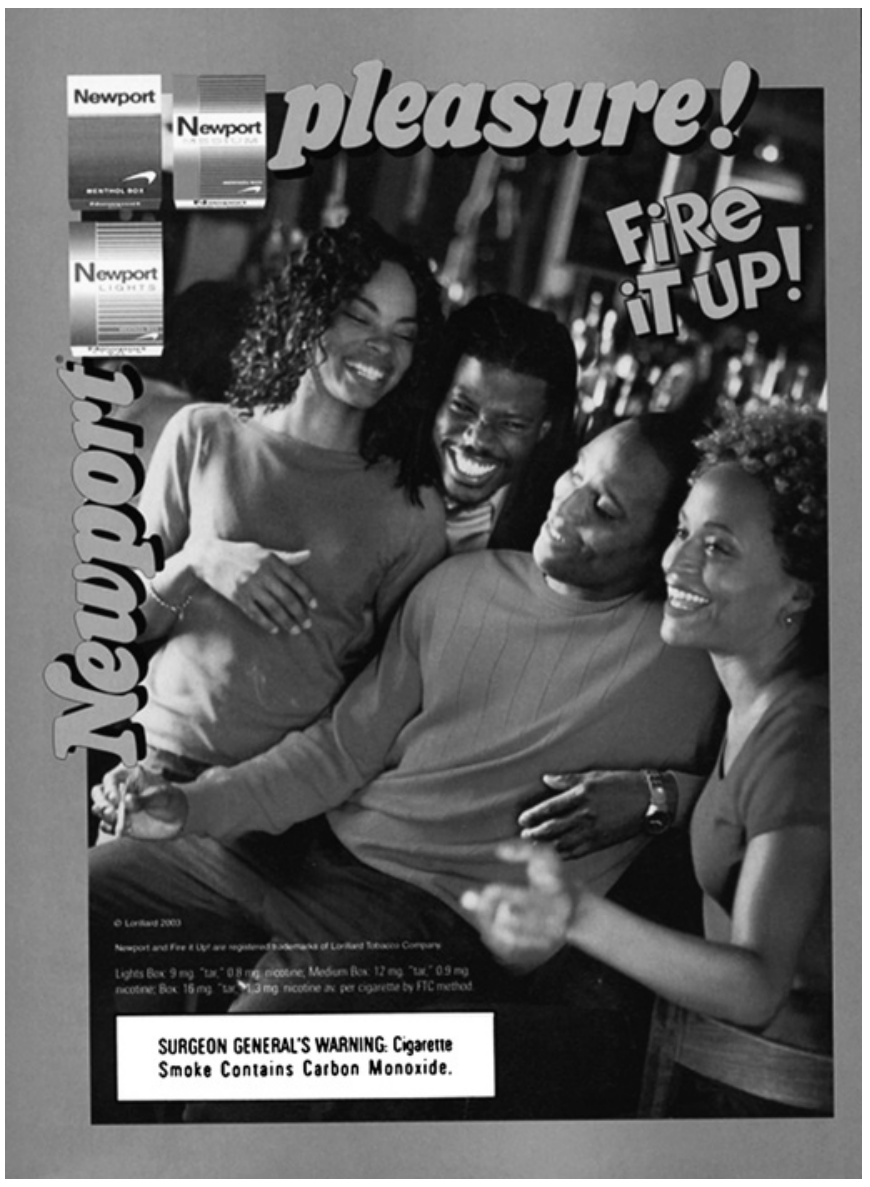

Figure 3 This 2003 Newport advertisement communicates fun-loving youthfulness and sociability, as well as in-group belonging (AfricanAmericans in an urban bar scene). The 'Alive with Pleasure' slogan of the 1990s is here replaced with simply 'Pleasure', further removing the campaign explicit health claims while continuing in the theme of the previous campaign that includes the health-suggestive word 'Alive' (image retrieved from http://www.trinketsandtrash.org).

connotation that menthol has health overtones', ${ }^{58}$ and that the Kool Super Lights line extension's 'menthol and tar delivery has synergistic therapeutic implications'. ${ }^{8}$ Such perceptions are exemplified in the statement of a respondent in a marketing study for B\&W in 1980, "that menthol cigarettes are better for you'. ${ }^{59}$

In 1975 (estimated date), Lorillard recognised the perception of protection against throat irritation as a boon to the company:

Overall, menthol smokers appear to be a prime target for a lowirritation story because they seem to be very conscious of irritation. It is highly identifiable by them, and they already view menthol cigarettes as the best route to diminish irritation. Therefore, they would not have to be 'sold' on the idea that a menthol cigarette and diminished irritation are compatible. ${ }^{60}$

As RJR stated in a 1977 analysis of the potential for share growth with 'high filtration' menthol products, '(t)he health concern was perhaps the primary motive for switching to menthol in the first place. In the hierarchy of product benefits/ attributes desired by menthol filter smokers, throat concerns rank just behind generic taste and satisfaction'. ${ }^{6}$

Smokers perceive 'mild' cigarettes as healthier than regular (non-'light') cigarettes. ${ }^{62-65}$ Menthol's perception as a milder and therefore safer product as compared to 'regular' cigarettes has caused switching from non-menthol to menthol brands and styles. In a 1976 marketing plan for a 'low-tar' menthol cigarette, B\&W asserted that 'Menthols and particularly Hi-Fi's (high filtration cigarettes) have a net gain from brand switching, ${ }^{57}$ The Sherman Group Inc. conducted a reconnaissance study of Newport for RJR in 1976 and found among young people:

(i)n rejecting the 'regular' cigarette taste, the smokers are referring back to their own experiences. These young smokers began smoking the 'popular' brands, Winston, Marlboro, Tareyton and Kents, etc, and moved to menthols for a variety of reasons or circumstances; the rejection of tobacco taste, the search for a 'milder' cigarette, personal influence, or the circumstances of having a cold and wanting to continue smoking, but being unable to 'handle' the hot taste of cigarettes in an already irritated throat. $^{66}$

Lorillard observed in 1972 that '(b)rand-switching has resulted in a $13 \%$ gain for Menthols which is larger than the $8 \%$ for $\mathrm{Hi} \mathrm{Fi}$ brands, the only types gaining from claimed switching. 67

Beliefs about the health benefits of mentholated cigarettes prevent some potential quitters from quitting in favour of switching to a mentholated brand or style. A William Esty Co. study for RJR in 1973 stated:

Generally when a respondent reported that he made a conscious decision to switch to a mentholated brand it was because of some problem, minor or major. For instance, many switched to mentholated cigarettes because of throat irritation, colds, coughs or chronic bronchitis. Sometimes respondents saw smoking a mentholated brand as the only alternative to giving up smoking altogether. ${ }^{68}$ (Emphasis added.)

The Roper Organization prepared a study for PM in 1979 on the attitudes of menthol smokers and that '(m)enthol smokers express slightly less desire to quit smoking than do non-menthol smokers-39\% would like to quit, versus $43 \%$ of non-menthol smokers' ${ }^{69}$ Burrows' analysis of key market trends of the 1960s concluded the tendency to switch from non-menthol to menthol rather than quit was important for Kool's rise in this decade:

The key trend for Kool was the emerging importance of younger adult Black smokers in the market. In the health-concerned 1960s, younger adult Blacks didn't back off from smoking to the extent that Whites did. Because of this, their importance surged from $6 \%$ of 18 -year-old smokers in the 1950 s, to $10 \%$ in the 1960 s. $^{42}$

\section{Marketing menthol cigarettes to specific populations African-Americans}

Advertisements for menthol cigarettes have been overrepresented in popular African-American magazines relative to non-African-American magazines ${ }^{11} 7071$ and in predominantly African-American urban neighborhoods. ${ }^{72}$ RJR stated in an in-house presentation on the 'US cigarette market in the 1990s (that) $95 \%$ of black younger adult smokers now choose menthol, and Newport has a 73 (percent) share-of-smoker among this group'. ${ }^{73}$

As an assessment of the menthol market from PM in 1986 recognised, '(r)elative to all smokers, menthol smokers tend to be: women, young (mainly 25-34), Black, light smokers $(<20$ cigarettes a day), lower-income earners, pack buyers, (and) 100 mm smokers'. ${ }^{74}$ PM had earlier seen, in 1968, that menthol 'was a product which by some virtue was especially suited to the needs, desires and tastes of Negro consumers', speculating that the 'great enthusiasm for menthol cigarettes... was based both on dynamic sensory and on psychological gratifications'. 75 
To exploit the 'potential opportunity sector' represented by black smokers, RJR produced a 'Black Opportunity Analysis' in $1985 .{ }^{76}$ RJR noted, '( $t$ )here are... gaps within Blacks. Several studies have suggested that Blacks are becoming polarized into an 'elite' and an 'underclass'.... It is the 'underclass' who are smokers'. ${ }^{76}$ Acknowledging the disadvantages of underclass status, RJR concluded that, although health may be a concern, 'Blacks simply have more pressing concerns than smoking issues'. ${ }^{76}$ The implication is that this market, with its myriad socioeconomic pressures, should remain reliable consumers even if they are aware of tobacco's health risks.

Heavy targeting of largely African-American urban populations is reflected in corresponding menthol brands and styles accounting for the bulk of African-American urban smoking. A 1983 'Cigarette Attitude Study (Among low-income Black smokers)' for Newport revealed ' $(t)$ he use of menthol cigarettes among the 18-34 lower-income Black segment is almost universal. Nearly 9 out of 10 smokers currently smoke a menthol brand' ${ }^{77}$ Noting changes from data in 1979, the study observed that '(o)verall, black smokers have better recall of advertising for specific menthol brands than in 1979' and 'showed a lower frequency of purchasing secondary brands, and more longevity with regard to the length of time current brand was smoked'.77 $\mathrm{B} \& \mathrm{~W}$ found in 1993 that 'Blacks are three times as likely to smoke menthol and four times as likely to smoke full revenue menthol compared to non-Blacks'. ${ }^{78}$

\section{Other populations: young people, women and Asians}

Although the preponderance of menthol usage among AfricanAmerican smokers is widely known and important, most menthol cigarettes are smoked by non-black populations. B\&W's 1993 study found that although $72.3 \%$ of black smokers used menthol compared to $25.3 \%$ of non-black smokers, the total menthol market was $73.5 \%$ non-black and only $26.4 \%$ black..$^{78}$

A 1983 study in the Lorillard collection on its Newport market found that:

(t)he three leading menthol brands exhibit distinct user profiles. Newport smokers tend to be younger (18-21), single and less educated. (B\&W's) Kool is smoked more by men, those over 25 years of age and those with even slightly lower incomes. (RJR's) Salem users are more often female, over age 25, more likely to be married, and more often employed.... Younger smokers (18-24) were most concerned with brand(s) smoked by family members and/or friends, and women were more frequently interested in a mild tasting product. ${ }^{77}$

Menthol styles are often lumped together by tobacco marketers in marketing language such as RJR's 'Coolness Segment'. Consumers in this segment 'are the youngest, the most economically disadvantaged, and the most likely to be in minority and ethnic groups', ${ }^{50}$ who 'tend, more than average, to desire their brand of cigarettes to symbolize personal qualities such as youth; modern womanhood; romance; career orientation; and success'. ${ }^{50}$ Recognising the brand-specific image consciousness of the segment, RJR stated, "brands in the Coolness Segment gain little or no imagery directly from the fact of their mentholation. Rather, they are able to develop a wide diversity of images'. ${ }^{50}$

The three largest standalone menthol brands, Kool, Newport and Salem, have different brand identities in the minds of the manufacturers and the consumers. RJR noted in 1977 that Salem was characterised by 'worried' smokers' and smokers who are 'passive, feminine'. ${ }^{79}$ RJR appears to have embraced this image in 1981 particularly with its Salem Slim Lights line extension, positioning it for consumers 'who desire a refreshing, low-tar cigarette with (a) stylish, unpretentious, feminine image'. ${ }^{48}$ Though the menthol segment 'skews female' (female consumers are overrepresented in the segment), ${ }^{80-82} \mathrm{~B} \& \mathrm{~W}$ 's Kool has a more masculine image than the other standalone brands. Lorillard noted in 1994 that 'Kool is viewed as a strong tasting, 'tough guy' cigarette'. ${ }^{83}$

Of the major menthol brands, Lorillard's Newport was 'the brand with the youngest demographics in the industry' according to a 1992 Lorillard report. ${ }^{84}$ Newport's marketing strategy through much of the 1990s was to 'continue to improve Newport's appeal as the 'peer' brand among younger adult smokers' ${ }^{85} 86$ Part of the strategy was to 'develop an 'attack plan' to establish an offensive posture in the general market to more aggressively compete with Marlboro Menthol in select markets' ${ }^{87}$ 'General market', a term denoting the overall cigarette market, is contrasted here with 'urban center', ${ }^{87}$ the term for young inner city African-Americans. This attack plan included marketing initiatives to 'continue to define 'Newport Pleasure' in a variety of different ways: social interactions, 'zany' fun, smoking situations, intimate moments, and refreshment'.

\section{DISCUSSION}

Menthol cigarettes were originally marketed on a health platform, and health messages convinced consumers that menthol cigarettes were healthier for them than non-menthol cigarettes. Descriptors and colouring of cigarette packs communicate health information to consumers with no actual mention of health. ${ }^{88}$ Associations of menthol with health continue to this day, although health assurance marketing messages for menthol cigarettes have become more oblique.

There is not a single menthol user image across all mentholated products. The overrepresentation of African-Americans in the menthol cigarette market is widely discussed in the academic literature, ${ }^{70} 72{ }^{89-91}$ but in sheer numbers, more non-African-American smokers use menthol. It is important to examine if and how menthol products have been marketed to various other populations (eg, women, other ethnic/racial groups as well as African-Americans). Women and girls, as well as some ethnic/racial groups, are important potential consumers for the tobacco industry in the US and abroad in nations where smoking rates in these groups are currently low. Similar to Virginia Slims' targeting of women in the second wave of the feminist movement in the 1960s and 1970s with a product superficially designed for them and an aggressive marketing campaign, ${ }^{92}$ menthol products, particularly Kool and Newport, aggressively targeted young black populations with socially relevant messages of in-group identity.

Menthol is also targeted to young people and women in the US. Consistent with the current findings, research in 2010 showed that in addition to a higher prevalence of menthol use among African-American men and women, female smokers of all races used mentholated cigarettes at higher than male smokers. ${ }^{93-95}$ The 'young female skew' of menthol is evident not only within the borders of the US, however; menthol is strongly represented among young women in Asian countries. Although different menthol brands present their own brand personalities (such as Kool being perceived largely as an AfricanAmerican man's cigarette in the US), menthol in general is perceived to be for women, younger people and lighter smokers. There is some international agreement on this latter point. That menthol skews female is particularly evident in studies of 
Asians, Pacific Islanders and Asian-Americans. In 1991, PM analysed the four Asian countries most important to PM Asia's growth: Japan, Hong Kong, Korea and Singapore, and noted that:

Salem King Size and Salem Lights are attracting a high proportion of young adult smokers under 25, traditionally the stronghold of the Marlboro franchise. The Salem franchise is also attracting a high proportion of young adult women, in markets where the incidence of young adult female smokers is growing as women become more emancipated. ${ }^{96}$

A 1985 study for B\&W on menthol in Japan showed that "menthol cigarettes tended to be considered as "fashionable" and that 'those who smoke menthol brands are somewhat 'different' people, if they were not young women'. ${ }^{97}$ The report advised that these aspects 'should be seriously considered by a marketer of menthol cigarettes since the primary target segment is younger women, that is, female students and office girls'. ${ }^{97}$ Marketing that emphasises coolness, refreshing sensations, mildness, soothing taste, and youthful, fun-loving imagery contributes to these perceptions.

Further evidence that these results replicate outside the US borders, the perception of health benefits of menthol over non-menthol has become global. A 1991 study by ASI Market Research Inc. in Japan for PM noted that men in particular '( $t$ )ried (menthol cigarettes) when not in good physical condition/when throat was feeling sore, and found them enjoyable'. 98 This report also noted that '( $\mathrm{m})$ enthol cigarettes were also felt to be somehow better for the health than nonmenthol cigarettes (ie, gentler on the throat)'. ${ }^{98}$ Marketing Decision Research (Pacific) Ltd. found similar results in a 1992 study of Hong Kong for PM:

The 'cooling' and 'refreshing' abilities of menthol have the following advantages:

- make smokers feel comfortable

- less easy to cause throat discomfort..

can also elate one's spirit but is much better than strong stimulation of nicotine in full-flavored cigarettes. It is relatively healthier. ${ }^{99}$ (Emphasis added.)

A 1979 study by PACC Information Systems showed B\&W that in Kuwait:

(M)enthol cigarettes are thought to present many good aspects; they are usually...

- relieving

- help to expell (sic) catharr (inflammation of the mucous membranes)

- help in the case of colds...

(M)enthol cigarettes are thought to be less harmful to health than ordinary cigarettes. ${ }^{100}$

These documents demonstrate that what the US tobacco companies do affects consumers around the globe. Transnational tobacco companies based in the US study consumers home and abroad, and it is not always clear which study or studies a certain bit of insight about effective marketing efforts originally came from. The consumer studies in Asia and in Kuwait echoing those that were conducted in the US reflect an interesting finding that US tobacco company activities are relevant beyond the borders of the US. Including menthol in the US FDA's list of banned cigarette flavouring additives as a policy measure help may lay a foundation for positive public health effects beyond the US borders in the future as well.

Menthol products have been marketed as, and are often perceived as, milder than 'regular' cigarettes and therefore less of a threat to health, similar to perceptions of 'low-tar' and 'light'

\section{What this paper adds}

Marketing for menthol cigarettes targets specific populations in the US, such as African-Americans. Less is known about what specific messages are communicated in marketing for different populations or about how consumers perceive messages in menthol cigarette marketing.

- Menthol cigarettes were marketed as, and are perceived by consumers to be, healthier than non-menthol cigarettes. Additionally, menthol marketing targeting African-Americans, young people and women is perceived by these groups to signal social group belonging.

- Menthol consumers (new initiators and established healthconcerned smokers) believe that menthol makes cigarettes easier and more palatable to smoke.

products. Whereas menthol users appear less interested in 'tar' than traditional health-concerned smokers who seek 'light' and 'ultralight' styles, the perception of health-protective effects of menthol makes menthol products function similarly to 'light' products. The products attract consumers who may otherwise quit smoking and provide psychological health assurances to continuing smokers.

Based upon the findings of this study, it appears the importance of menthol to the tobacco industry (and likely a reason that the industry opposes menthol's inclusion in the FDA's list of banned additives) is that menthol makes cigarettes easier and more palatable to smoke for new initiators and for established health-concerned smokers. Making cigarettes more attractive to new smokers and less desirable to quit among established smokers contributes to the incidence of tobacco-related diseases; menthol should be included on the list of banned additives.

Acknowledgements I thank Karen Butter, University Librarian, University of California San Francisco, for procuring the funding for this project.

Funding This research was supported by the Department of Health and Human Services Contract HHSN261201000035I.

\section{Competing interests None.}

Contributors SJA designed the study; collected, analysed, and interpreted the data; drafted the manuscript; and gave final approval to the manuscript.

Provenance and peer review Not commissioned; externally peer reviewed. This peer-reviewed paper is based on a longer, more detailed (but not peer reviewed) white paper prepared for the US Food and Drug Administration. The full white paper is available at http://www.escholarship.org/uc/item/33d643pd and http://www.fda. gov/downloads/AdvisoryCommittees/CommitteesMeetingMaterials/Tobacco ProductsScientificAdvisoryCommittee/UCM228120.pdf for download.

\section{REFERENCES}

1. Ahijevych K, Garrett BE. Menthol pharmacology and its potential impact on cigarette smoking behavior. Nicotine Tob Res 2004:6(Suppl 1):S17-28.

2. Covington \& Burling. Summary of Data on Menthol. Brown \& Williamson, 1986 http://legacy.library.ucsf.edu/tid/isn33f00.

3. Mitka M. FDA exercises new authority to regulate tobacco products, but some limits remain. JAMA 2009;302:2078, 2080-1.

4. Pollay RW, Dewhirst T. The dark side of marketing seemingly "light" cigarettes: successful images and failed fact. Tob Control 2002;11(Suppl 1):118-31.

5. Kreslake JM, Wayne GF, Alpert HR, et al. Tobacco industry control of menthol in cigarettes and targeting of adolescents and young adults. Am J Pub Health 2008;98:1685-92.

6. Kreslake JM, Wayne GF, Connolly GN. The menthol smoker: tobacco industry research on consumer sensory perception of menthol cigarettes and its role in smoking behavior. Nicotine Tob Res 2008;10:705-15.

7. Davis RM, Gilpin EA, Loken B, et al, eds. The Role of the Media in Promoting and Reducing Tobacco Use. National Cancer Institute Tobacco Control Monograph Series Monograph 19. NIH Publication No. 07-6242. Bethesda MD: US Department of 
Health and Human Services, 2008. http://cancercontrol.cancer.gov/tcrb/ monographs/19/index.html.

8. Muggli ME, Pollay RW, Lew R, et al. Targeting of Asian Americans and Pacific Islanders by the tobacco industry: research from the Minnesota Tobacco Documents Depository. Tob Control 2002;11:201-9.

9. Hafez N, Ling PM. Finding the Kool Mixx: how Brown \& Williamson used music marketing to sell cigarettes. Tob Control 2006;15:359-66.

10. Samji H, Jackler R. "Not one single case of throat irritation": misuse of the image of the otolaryngologist in cigarette advertising. Laryngoscope 2008:118:415-27.

11. Sutton C, Robinson R. The marketing of menthol cigarettes in the United States: populations, messages, and channels. Nicotine Tob Res 2004;6(Suppl 1):S83-91.

12. Solow JL. Exorcising the ghost of cigarette advertising past: collusion, regulation, and fear advertising. J Macromarketing 2001;21:135-45.

13. US Department of Health Education and Welfare. Smoking and Health: Report of the Advisory Committee to the Surgeon General of the Public Health Service. Washington, DC: US Department of Health Education and Welfare, Public Health Service, Center for Disease Control, 1964.

14. Kovacic WE. Prepared statement of the Federal Trade Commission before the Committee on Commerce, Science, and Transportation. United States Senate: US Federal Trade Commission, 2007. http://www.ftc.gov/os/testimony/

P064508tobacco.pdf (accessed 23 Aug 2010).

15. Anderson S, Pollay R, Ling P. Taking ad-vantage of lax advertising regulation in the USA and Canada: reassuring and distracting health-concerned smokers. Soc Sci Med 2006;63:1973-85.

16. Bates C, McNeill A, Jarvis $\mathrm{M}$, et al. The future of tobacco product regulation and labelling in europe: implications for the forthcoming european union directive. Tob Control 1999;8:225-35.

17. Djordjevic M, Stellman S, Zang E. Doses of nicotine and lung carcinogens delivered to cigarette smokers. J Natl Cancer Inst 2000;92:106-11.

18. Hoffman D, Hoffman I. The changing cigarette, 1950-1995. J Toxicol Environ Health 1997:50:307-64.

19. Jarvis M, Boreham R, Primatesta P, et al. Nicotine yield from machine-smoked cigarettes and nicotine intakes in smokers: evidence from a representative population survey. J Nat/ Cancer Inst 2001;93:134-8.

20. Leavell N. The low tar lie. Tob Control 1999;8:433-7.

21. Healton CG, Beck SE, Cartwright J, et al. Prohibiting menthol in tobacco products: a policy whose time has come. Addiction 2010;105(Suppl 1):5-7.

22. Anderson SJ, McCandless PM, Klausner K, et al. Tobacco documents research methodology. Tobacco Control 2011;20(Suppl 2):iï-ii11.

23. Malone RE, Balbach ED. Tobacco industry documents: treasure trove or quagmire? Tob Control 2000;9:334-8

24. Miles MB, Huberman AM. Qualitative Data Analysis: An Expanded Sourcebook. 2nd edn. Thousand Oaks, CA: Sage Publications Inc, 1994.

25. Bero L. Implications of the tobacco industry documents for public health and policy. Annu Rev Public Health 2003:24:267-88.

26. American Tobacco. Publicity Articles, Appearing in Periodicals From 1929-1947. American Tobacco, undated. http://legacy.library.ucsf.edu/tid/mxu51a00.

27. Reid JR. A History of Mentholated Cigarettes 'This Spud's for You'. Philip Morris, 1993. http://legacy.library.ucsf.edu/tid/nqf32e00 (estimated date).

28. Market Science Associates Inc. A Report Entitled "The Growth of Menthols 330000-770000". Brown \& Williamson, 1933. http://legacy.library.ucsf.edu/tid/ dtd30f00.

29. Brown \& Williamson. $B \&$ W. RJ Reynolds, 1978. http://legacy.library.ucsf.edu/ tid/cwt76a00.

30. Brown \& Williamson. Kool. Brown \& Williamson. http://legacy.library.ucsf.edu/tid/ tuk60f00.

31. Lorillard. Unfair or Deceptive Advertising and Labeling of Cigarettes in Relation to the Health Hazards or Smoking. Lorillard, 1964. http://legacy.library.ucsf.edu/tid/ keb00e00 (estimated date)

32. Cunningham and Walsh. Kool: 1933-1980-a Retrospective View of Kool-Book I: The Text. Research, 1980. http://legacy.library.ucsf.edu/tid/nso56b00.

33. Bernstein A. Brown \& Williamson Tobacco Corporation, Evaluation of Major Brands, 1954-1964. American Tobacco, 1964. http://legacy.library.ucsf.edu/tid/ bvv25f00.

34. Lorillard. Kent Menthol 100's. Lorillard, 1973. http://legacy.library.ucsf.edu/tid/ dud20e00.

35. Brown \& Williamson. Kool Family Utopian Objectives 1979-1985. Research, 1978. http://legacy.library.ucsf.edu/tid/xjm66b00 (estimated).

36. Norr R. Cancer By the Carton. Brown \& Williamson, 1952. http://legacy.library.ucsf. edu/tid/kap01f00.

37. Brown \& Williamson. Menthol Market Presentation. Brown \& Williamson, 1982. http://legacy.library.ucsf.edu/tid/khx01f00.

38. Brown \& Williamson. File Note. Kool Advertising 480000 to 680000 . Brown \& Williamson, 1968. http://legacy.library.ucsf.edu/tid/uyi70f00.

39. Philip Morris. Menthol Review. Philip Morris, 1988. http://legacy.library.ucsf.edu/ tid/rpy92e00 (estimated date).

40. A.D.I. Research Inc. B\&W Cigarette Smokers Study. Brown \& Williamson, 1984. http://legacy.library.ucsf.edu/tid/nwo83f00

41. Cunningham \& Walsh. Kool International-Campaign Extension Strategic Platform. Brown \& Williamson, 1984. http://legacy.library.ucsf.edu/tid/cej60f00.

42. Burrows DS. Strategic Research Report. Younger Adult Strategies and Opportunities. RJ Reynolds, 1984. http://legacy.library.ucsf.edu/tid/ene39d00.
43. Broughton JA. The B\&W Success Story. Brown \& Williamson, 1966. http://legacy. library.ucsf.edu/tid/tey04f00.

44. Brown \& Williamson. Brown \& Williamson Tobacco Corporation 690000 Marketing Plans. Brown \& Williamson, 1969. http://legacy.library.ucsf.edu/tid/ caf10f00.

45. Schreiber MB. Kool Creative. Brown \& Williamson, 1983. http://legacy.library.ucsf. edu/tid/iea40f00.

46. Leo Burnett. Menthol "Creative Platform" Exploration Research. Philip Morris, 1995. http://legacy.library.ucsf.edu/tid//xl27a00.

47. Kapuler Marketing Research Inc. Kool Asian Creative Evaluation Final Report. Research, 1988. http://legacy.library.ucsf.edu/tid/rxb86b00.

48. RJ Reynolds. Coolness Segment Overview. RJ Reynolds, 1981. http://legacy. library.ucsf.edu/tid/zqc95d00.

49. RJ Reynolds. Copy Strategy Salem. RJ Reynolds, 1981. http://legacy.library.ucsf. edu/tid/cel85d00.

50. RJ Reynolds. Strategic Research Report: The 1981 Brand Family Segmentation Study. Mangini, 1982. http://legacy.library.ucsf.edu/tid/ngy52d00.

51. RJ Reynolds. 1982(820000) m-2 National Introductory Plan. Positioning RJ Reynolds, 1982. http://legacy.library.ucsf.edu/tid/jbm19d00.

52. Lorillard. A Pretest Evaluation of an Outdoor Design For Newport Cigarettes Newport Alive With Pleasure. Lorillard, 1977. http://legacy.library.ucsf.edu/tid/ydy31e00

53. RJ Reynolds. Coolness Segment. RJ Reynolds, 1985. http://legacy.library.ucsf edu/tid/arx18c00.

54. Leo Burnett. Review of New Menthol Brands. Philip Morris, 1995. http://legacy. library.ucsf.edu/tid/gaa37c00.

55. United States District Court for the District of Columbia. United States of America, Plaintiff, and Tobacco-Free Kids Fund, American Cancer Society, American Heart Association, American Lung Association, Americans for Nonsmokers' Rights, and National African American Tobacco Prevention Network, Intervenors v. Philip Morris Incorporated, et al. Defendants. Civil Action No. 99-CV-02496 (GK). Washington, DC: United States District Court for the District of Columbia, 2006. i-2454.

56. Batten Barton Durstine \& Osborn Inc. Focused Group Interviews Conducted in New York and Minneapolis on Tennyson Cigarettes. American Tobacco, 1969. http://legacy.library.ucsf.edu/tid/boo21a00.

57. Brown \& Williamson. Low Tar Longs Project Creative Agency Assignment. Brown \& Williamson, 1976. http://legacy.library.ucsf.edu/tid/ssu60f00.

58. Johnson R. - No Title. Brown \& Williamson, 1978. http://legacy.library.ucsf.edu/ tid/wde21f00.

59. Goett J. Smoking Motivation Study. Brown \& Williamson, 1980. http://legacy. library.ucsf.edu/tid/kliz3fo0.

60. Lorillard. An Exploratory Study - Menthol Smokers' Perceptions of Irritation From Cigarettes. Lorillard, 1975. http://legacy.library.ucsf.edu/tid/dys31e00 (estimated date).

61. RJ Reynolds. Project " $Y$ " Secret. RJ Reynolds, 1977. http://legacy.library.ucsf.edu/ tid/dxt79d00.

62. Wilson N, Weerasekera D, Peace J, et al. Misperceptions of "light" cigarettes abound: national survey data. BMC Public Health 2009;8:126.

63. Assunta $\mathbf{M}$, Chapman S. The lightest market in the world: light and mild cigarettes in Japan. Nicotine Tob Res 2008;10:803-10.

64. Borland R, Fong GT, Yong HH, et al. What happened to smokers' beliefs about light cigarettes when "light/mild" brand descriptors were banned in the UK? Findings from the International Tobacco Control (ITC) Four Country Survey. Tob Control 2008:17:256-62.

65. Anderson SJ, Ling PM, Glantz SA. Implications of the federal court order banning the terms "light" and "mild": what difference could it make? Tob Control 2007:16:275-9

66. Sherman Group. Insights into Newport. An Exploratory Study in Brand Perceptions. RJ Reynolds, 1976. http://legacy.library.ucsf.edu/tid/fcb49d00.

67. Lorillard. The Menthol Cigarette Market-A Summary. Research, 1972. http:// legacy.library.ucsf.edu/tid/yrm76b00.

68. William Esty Inc. Salem Cigarettes. Attitudes and Behavior With Respect to Mentholated Cigarettes. RJ Reynolds, 1973. http://legacy.library.ucsf.edu/tid/ wad39d00.

69. Roper Organization Inc. A Study of Smokers' Habits and Attitudes With Special Emphasis on Low Tar and Menthol Cigarettes Volume I. Research, 1979. http:// legacy.library.ucsf.edu/tid/zvt46b00.

70. Landrine H, Klonoff E, Fernandez S, et al. Cigarette advertising in Black, Latino, and White magazines, 1998-2002: an exploratory investigation. Ethn Dis 2005;15:63-7.

71. Cummings K, Giovino G, Mendicino A. Cigarette advertising and black-white differences in brand preference. Public Health Rep 1987;102:698-701.

72. Yerger V, Przewoznik J, Malone R. Racialized geography, corporate activity, and health disparities: tobacco industry targeting of inner cities. J Health Care Poor Underserved 2007;18(Suppl 4):10-38.

73. RJ Reynolds. U.S. Cigarette Market in the 1990s. Tobacco Institute. http://legacy. library.ucsf.edu/tid/yzs91f00

74. Philip Morris. The Declining Menthol Market. Philip Morris, 1986. http://legacy. library.ucsf.edu/tid/hhv55e00 (estimated date).

75. Tibor Koeves Associates. A Pilot Look at the Attitudes of Negro Smokers Toward Menthol Cigarettes. Philip Morris, 1968. http://legacy.library.ucsf.edu/tid/tdp54e00.

76. RJ Reynolds. RJ Reynolds. Black Opportunity Analysis. Research, 1985. http:// legacy.library.ucsf.edu/tid/tuu46b00. 
77. Lorillard. Cigarette Attitude Study (Among Low Income Black Smokers). Research, 1983. http://legacy.library.ucsf.edu/tid/vrp76b00 (estimated).

78. Brown \& Williamson. 930000 Brand Switching Study Menthol. Brown \& Williamson, 1993. http://legacy.library.ucsf.edu/tid/sll02b00.

79. RJ Reynolds. Salem Informational Needs. RJ Reynolds, 1977. http://legacy.library. ucsf.edu/tid/zvk88d00.

80. Brown \& Williamson. Female Smokers. Brown \& Williamson, 1988. http://legacy. library.ucsf.edu/tid/iom90f00.

81. Camisa RJ. Generic Re-Positioning of Alpine. Philip Morris, 1987. http://legacy. library.ucsf.edu/tid/sqa03e00.

82. Zolper S. New Product Development Charter. Dakota M. Brown \& Williamson, 1987. http://legacy.library.ucsf.edu/tid/vmf61f00.

83. Day RH, Henderson NR. Final Report on Eight Focus Groups With Black and White Users of Newport, Salem, and Kool Cigarettes on Issues Related to Newport Cigarettes and its Advertising Campaign. Lorillard, 1994. http://legacy.library.ucsf. edu/tid/dzn54a00.

84. Lorillard. Newport 920000 Corporate Product Line Marketing Role. Lorillard, 1992. http://legacy.library.ucsf.edu/tid/bbv44a00 (estimated date).

85. Lorillard. Newport Marketing Strategies 950000. Lorillard, 1995. http://legacy. library.ucsf.edu/tid/cgk14a00.

86. Lorillard. Newport 980000 Marketing Strategies. Lorillard, 1998. http://legacy. library.ucsf.edu/tid/vmv35a00 (estimated date).

87. Lorillard. Newport 960000 Strategic Plan. Lorillard, 1995. http://legacy.library.ucsf. edu/tid/hun54a00

88. Hammond D, Parkinson C. The impact of cigarette package design on perceptions of risk. J Pub Health 2009:31:345-53.

89. Allen B Jr, Unger J. Sociocultural correlates of menthol cigarette smoking among adult african americans in los angeles. Nicotine Tob Res 2007:9:447-51.
90. Gardiner P. The african americanization of menthol cigarette use in the united states. Nicotine Tob Res 2004;6(Suppl 1):S55-65.

91. Mustonen T, Spencer S, Hoskinson R, et al. The influence of gender, race, and menthol content on tobacco exposure measures. Nicotine Tob Res 2005:7 581-90.

92. Amos A, Haglund M. From social taboo to "torch of freedom": the marketing of cigarettes to women. Tob Control 2000;9:3-8.

93. Lawrence D, Rose A, Fagan $\mathrm{P}$, et al. National patterns and correlates of mentholated cigarette use in the United States. Addiction 2010:105(Suppl 1):13-31.

94. Cubbin C, Soobader MJ, LeClere FB. The intersection of gender and race/ethnicity in smoking behaviors in menthol and non-menthol smokers in the United States. Addiction 2010;105(Suppl 1):32-8.

95. Fernander $\mathbf{A}$, Rayens MK, Zhang $M$, et al. Are age of smoking initiation and purchasing patterns associated with menthol smoking? Addiction 2010;105(Suppl 1):39-45

96. Philip Morris International. Phillip Morris International Annual Marketing Meeting PM Asia New Products. Philip Morris, 1991. http://legacy.library.ucsf.edu/tid/ zrh81c00.

97. A \& M Incorporated International Creative Marketing. Final Report: Perception and Attitude Study on Menthol Cigarettes. Japan-840000. Brown \& Williamson, 1985. http://legacy.library.ucsf.edu/tid/tgj60f00.

98. ASI Market Research Inc. Qualitative Research on Menthol Nonmenthol Smokers. Research, 1991. http://legacy.library.ucsf.edu/tid/bhi86b00.

99. Marketing Decision Research (Pacific) Ltd. Project 'Fresh Start'-A Report. Philip Morris, 1992. http://legacy.library.ucsf.edu/tid/asw81f00 (estimated date).

100. PACC information Systems. Qualitative Research on Menthol Cigarettes in Kuwait. Findings of the Focus Group. Brown \& Williamson, 1979. http://legacy. library.ucsf.edu/tid/lbg70f00. 